\title{
Orthopox Viruses: Infections in Humans
}

\author{
Arbeitskreis Blut, Untergruppe «Bewertung Blutassoziierter Krankheitserreger»
}

\section{Current Knowledge about the Pathogen}

Human smallpox caused by the variola virus (VARV) presented a threat for humans world-wide for centuries. The successful eradication of smallpox was possible thanks to comprehensive vaccination programmes and quarantine measures under the auspices of the WHO in the 1970s. The last natural smallpox infection was described in Somalia in 1977 [1]. One year later, two VARV infections occurred in Great Britain which probably originated from a virus laboratory $[2,3]$. In late 1979 , the WHO finally declared smallpox to be eradicated [4].

Other poxviruses able to infect humans had up to that time only played a role in the event of a suspected VARV infection for differential diagnoses.

In 1796, Dr. Jenner showed that humans were protected against VARV infections after a cowpox virus (CPXV) infection. As was shown later, the reason for this was the pronounced cross-immunity between different animal orthopox viruses (OPV) and human smallpox virus. The OPV used later for systematic immunisation (vaccination) were called vaccinia virus $(\mathrm{VACV}$; lat. vacca $=$ the cow $)$. Earlier, and probably originating from China and India, protection from smallpox infections with lethal outcome was achieved by transmission of VARV from diseased persons to children who up to that time had not gone through a smallpox infection. In this procedure, which was called variolation, it was accepted that $1-2 \%$ of the children infected that way died of smallpox. As a rule, the course of the infection was milder than in the event of natural smallpox infection [5]. In 1796, variolation was replaced by vaccination with cowpox thanks to Jenner's work. Bavaria introduced compulsory smallpox vaccination as early as 1807, Prussia (and the Deutsche Reich (German empire)), however, introduced it later, in 1874. Accordingly, in 1871 only 89 people per 100,000 inhabitants died from smallpox in Munich, compared to 623 in Berlin.

\section{KARGER}

Fax +497614520714

Information@Karger.de

www.karger.com (c) 2010 S. Karger GmbH, Freiburg

Accessible online at:

www.karger.com/tmh
Together with a number of animal poxviruses, VARV is a member of the family of Poxviridae (table 1), subfamily of Chordopoxvirinae, genus Orthopoxvirus (OPV) (table 2).

Table 3 shows viruses of the Chordopoxvirinae subfamily, which are grouped to other genera and infect humans and cause symptoms of the disease. It is noteworthy that, apart from VARV, only the virus of molluscum contagiosum (dell warts), genus Molluscipoxvirus, is an exclusively human pathogen. All other poxviruses which can infect humans have animals as reservoir and are therefore to be classified in the group of zoonotic pathogens.

Since the eradication of human smallpox, infections with CPXV have been observed in Germany, but also in other European countries, to an increasing extent. The same applies to monkeypox virus (MPXV) in Africa and infections with VACV-like agents in some regions such as India and Brazil [6]. All these viruses belong to the genus of Orthopoxvirus and are transmitted to humans by contact with infected animals. The observed increase in infections is above all due to the fact that after the vaccinations against VARV were dis-

Table 1. Family Poxviridae

\begin{tabular}{ll}
\hline Subfamily & Genus \\
\hline Chordopoxvirinae & $\begin{array}{l}\text { orthopoxvirus (OPV) } \\
\text { avipoxvirus } \\
\text { capripoxvirus } \\
\text { leporipoxvirus } \\
\text { suipoxvirus } \\
\text { molluscipoxvirus (MOCV) } \\
\text { yatapoxvirus } \\
\text { other non-classified chordopoxviruses } \\
\text { alpha-entomopoxvirus } \\
\text { beta-entomopoxvirus } \\
\text { gamma-entomopoxvirus } \\
\text { other non-classified entomopoxviruses }\end{array}$ \\
\hline
\end{tabular}

Prof. Dr. med. Rainer Seitz

Paul-Ehrlich-Institut

Paul-Ehrlich-Straße 51-59, 63225 Langen, Germany

Tel. +49 6103 77-2601, Fax -1250

E-mail seira@pei.de 
Table 2. Orthopox viruses (OPV): Host and host specificity

\begin{tabular}{|c|c|c|c|}
\hline Virus & Infections in & Spectrum of hosts & Natural host \\
\hline Variola (VARV) & human & narrow & human \\
\hline Vaccinia (VACV) & human, buffalo, cattle, elephant, pig, rabbit, etc. & broad & unknown \\
\hline $\begin{array}{l}\text { VACV-like Brazilian isolates } \\
\text { (BRZ-VACV) }\end{array}$ & human, cattle, rodent & broad & rodent \\
\hline Buffalopox (BPXV-VACV) & buffalo, cattle, human & broad & \\
\hline Rabbitpox (RPV-VACV) & rabbits in breeding establishments & broad & \\
\hline Monkeypox (MPXV) & human, ape, monkey, rodent, prairie dog, etc. & broad & rodent, sciuridae \\
\hline Cowpox (CPXV) & $\begin{array}{l}\text { human, cat, cattle, elephant, rodent, } \\
\text { rhinoceros, etc. }\end{array}$ & broad & rodent \\
\hline Camelpox* (CMLV) & camel & narrow & unknown \\
\hline Ectromelia (ECTV) & mouse, laboratory mouse & narrow & vole? \\
\hline Racoonpox & racoon & broad? & unknown \\
\hline Volepox & vole, pinon mouse & narrow & vole \\
\hline Uasin-Gisha pox & horse & medium (?) & unknown \\
\hline Taterapox & tatera kempi (gerbil) & narrow & gerbil? \\
\hline
\end{tabular}

*Camelpox viruses show a very close relationship to VARV. Infections with camelpox virus in humans, however, have not been observed [133].

Table 3. Other chordopox viruses that can infect humans

\begin{tabular}{llll}
\hline Genus & Species & Clinical sign & Host \\
\hline Parapox virus & orfvirus & Orf; ecthyma contagiosum & sheep, goat, wild ruminant \\
& pseudo cowpox virus & Melker's nodule & cattle \\
& parapox in cattle (stomatitis papulosa & local infections & cattle \\
& virus of the cattle) & & \\
& seal parapox virus (SPPV) & local infections & seal \\
& reindeer parapox virus & local infections & reindeer \\
\hline Molluscipoxvirus & molluscum contagiosum virus & non-malignant tumours & human \\
\hline Yatapoxvirus & yaba monkey tumour virus & yaba monkey tumour & monkey \\
& tanapoxvirus & tanapox & monkey (rodent) \\
\hline
\end{tabular}

continued, the non-vaccinated, predominantly young population was no longer protected against OPV. Apart from MPXV infections, OPV infections in immunocompetent individuals usually take a self-limiting course. The only symptoms are local skin lesions, usually limited to the infection site, as well as general symptoms in the form of febrile lymphangitis and lymphadenitis. In the event of suspected poxvirus infection, contagious ecthyma, milker's nodule, herpes infections, actinomycosis, and anthrax would have to be ruled out in the differential diagnosis.

\subsection{Characteristics of Orthopoxvirus}

OPV are enveloped brick-shaped viruses $(350 \times 270 \mathrm{~nm})$ containing a double-stranded DNA genome with a size of approximately $200 \mathrm{~kb}$, the ends of which are connected by covalent links [7]. Morphologically, the different OPV species cannot be distinguished by means of electron microscopy (fig. 1).
In addition, OPV are closely related to each other with regard to antigens and show marked homology at the genome level. The genome of the poxviruses encodes for 150-200 different genes. Unlike other DNA viruses, poxviruses replicate in the cytoplasm of infected cells in so-called virus factories (Guarnieri inclusion bodies). Originally, four different infectious virus particles were distinguished during OPV replication: intracellular mature enveloped virus particles, intracellular enveloped virus particles, cell-associated enveloped virus particles, and extracellular enveloped virus particles. Both intracellular and extracellular viruses play an important part for pathogenesis. Intracellular and cell-associated viruses are involved in the spreading of the virus from cell to cell, whereas viruses released from the cell enable the dissemination within the infected organism.

The first stages of the infection of cells, such as adsorption and penetration into the cell, so far have not sufficiently been understood. Mature virus particles adhere to the cell membrane. The virus membrane then fuses with the cell mem- 


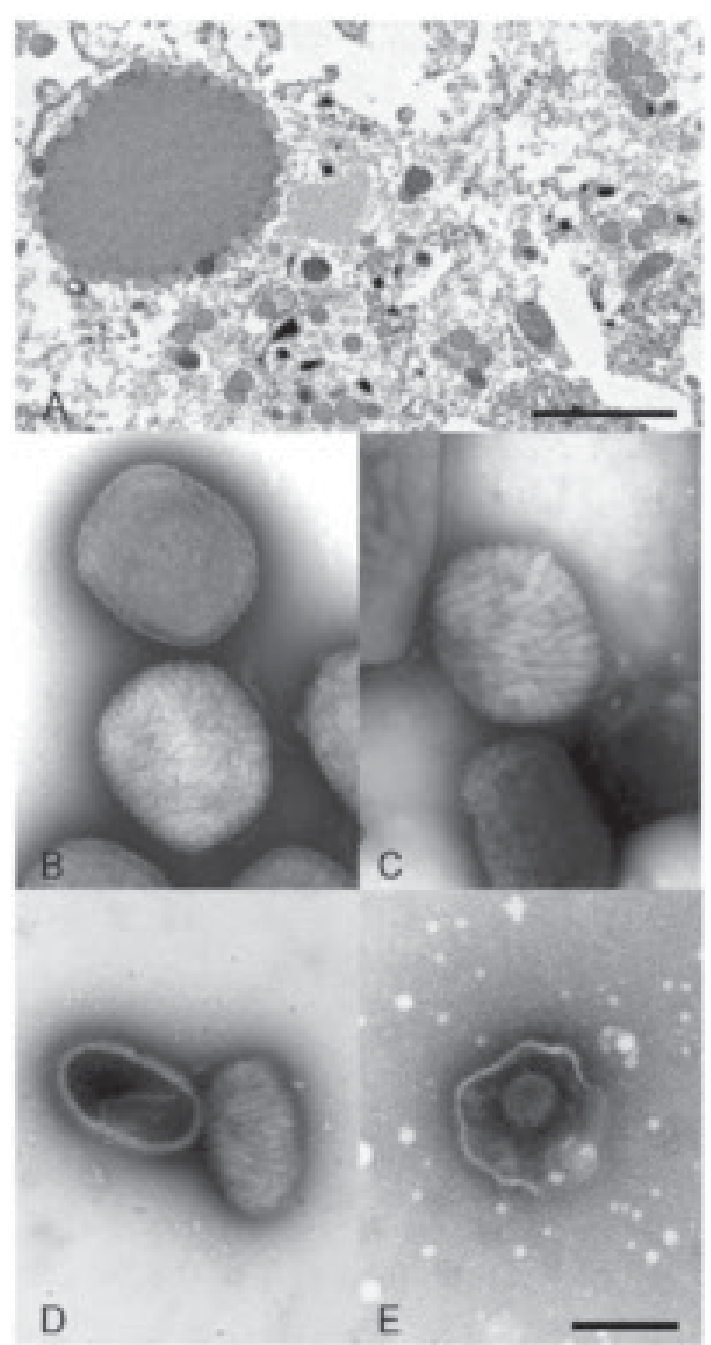

$2 \mu \mathrm{m}$

Fig. 1. A Electron microscopy: Ultra-thin section of an orthopox virus (OPV)-infected cell. In the cytoplasma (top left) an electron dense 'virus factory' is shown. At the surface of the 'factory' virus particles accumulate scattered around the surface. In addition round, immature particles with a clearly visible electron dense envelope can be detected, some with not fully closed envelope.

B-E Electron microscopy: Diagnostic negative contrasting of poxvirus and herpes virus.

B Two brick-shaped OPV particles with a typical, clearly visible surface structure. The upper particle is penetrated by the contrast stain to show the structure of its lipid membrane while the lower virion only shows its 'berry'-shaped surface (capsid shape versus mulberry shape of the lower particle).

C Molluscum contagiosum virus (MOCV) particles resemble OPV particles in size and shape. However, they also show a slightly different surface structure that can be used for differentiation.

D Parapox viruses (PPV; prototype is the orfvirus) are ovoid, show longer, partly parallel surface structures and are markedly smaller than OPV.

E Herpes virus from an exsudate used for diagnostic purposes: the capsid of $100 \mathrm{~nm}$ diameter with regular shape is still enveloped by the remains of a virus lipid shell.

Electron microscopy photography and compilation of the photos by Dr. Andreas Kurth; Robert Koch-Institut, Berlin. brane, releasing the virus core $[8,9]$. The virus particle, which has a complex structure, already contains a number of viral enzymes and regulatory proteins necessary for the first steps of virus replication. One of these proteins is involved in the cleavage of the cellular DNA and down-regulation of mRNA synthesis. Various enzymes and regulatory as well as virus structural proteins are expressed in a co-ordinated manner during replication. Transcription of the early genes through the viral DNA-dependent RNA polymerase present in the virus particle already starts in the virus core released into the cell. After replication of the virus genome by the viral DNAdependent DNA polymerases, synthesis of the intermediate and late gene products occurs [10]. DNA replication occurs within $6 \mathrm{~h}$, resulting in the production of up to 100,000 new copies per infected cell.

The synthesis of VACV particles occurs in areas of the cytoplasm which in electron microscopy appear as electron dense areas (fig. 1). Spherical particles with high electron density are formed which have a lipid membrane. These particles are then transported to the periphery of the cell where they are equipped with two additional lipid envelopes. After fusion of the external virus envelope membrane with the cell membrane, the virus particles are released and cell-associated and cell-free particles are observed.

Poxviruses encode a number of different proteins, which interfere as antagonists of cytokines with the immune response of the host. These viral proteins are important factors for pathogenesis [11, 12]. Three different activities can be distinguished in principle: virus-encoded homologues of cellular chemokine receptors, virus-encoded homologues of cellular chemokines as well as virus-encoded chemokine-binding proteins. In this context, the various different poxviruses have developed differing strategies which may be due to co-evolution of the viruses and the hosts.

Among poxviruses, members of the OPV genus have so far been studied most thoroughly. Therefore, comprehensive data are available mainly for these viruses. OPV are very stable in crusts and secretions and can remain infectious in the environment over a long period of time [13]. In aerosols, human poxviruses are rather resistant to environmental influences and can survive for $24 \mathrm{~h}$ in dependence of the ambient temperature and humidity $[14,15]$. Studies on the stability of OPV in crusts have been described in the literature. VARV survived in crusts for several weeks depending on the temperature and humidity $\left(3\right.$ weeks at $35{ }^{\circ} \mathrm{C}$ and $65-68 \%$ humidity, 8 weeks at $25.8-26.4{ }^{\circ} \mathrm{C}$ and $85-90 \%$ humidity, and 12 weeks at $25.8-26.4{ }^{\circ} \mathrm{C}$ and $<10 \%$ humidity [16]). According to other papers, VARV could be isolated from crusts obtained from individuals suffering from pox, which were dried and stored protected from light, after more than 1 year [17] or 13 years [18]. Calculations showed that under these experimental conditions, titres in the crusts decreased only by the factor of 100 after around 3,000 days [15]. Dried out on a glass slide, infectious VARV could be demonstrated even after 3 months [17]. 
In extensive studies, Tanabe and Hotta [19] tested the effect of disinfectants on VARV and VACV. We only list a few conventional disinfectants as examples here: within $1 \mathrm{~min}$, VARV was inactivated below the detection limit by $50-70 \%$ ethanol or $40-50 \%$ isopropanol, $0.1-2 \%$ sodium hypochlorite or $1 \%$ formaldehyde (reduction factor $\geq 10^{6}$ ).

In non-stabilised virus suspensions VACV was fully inactivated within 15 min during which it was heated to $65^{\circ} \mathrm{C}$ [20]. In addition, high stability was shown for VACV in foods and the environment [21].

\subsection{Infection and Infectious Disease}

\section{Human Poxvirus (Smallpox Virus, Variola Virus, VARV)}

In principle, we distinguish between two different courses of pox diseases: one caused by variola major virus infection and one caused by variola minor virus (also known as alastrim virus). Infections with variola major virus were characterised by a severe course of the infection with fatal outcome in a high percentage (20-50\%) of cases, whereas infection with the variola minor virus induced a milder course and only showed a mortality rate of approximately $1 \%$.

Transmission of human smallpox virus usually occurred by contact with droplets or aerosols. Therefore, the virus first infected cells of the nasopharynx or the mucosa of the respiratory tract. Epidemiological studies showed that only few infectious particles were sufficient for infection. The further replication of the virus occurred in the regional lymph nodes, followed by the first viraemic phase on the 3rd to 4th day after infection, which largely occurred asymptomatically. After that, the virus affected above all lymphatic organs such as the spleen, lymph nodes, and bone marrow. The second phase of viraemia started around the 8th day after infection, with infected leucocytes transporting the virus to the periphery of the body. There, in particular cells of the small blood vessels of the skin and the mucosae were infected. Around the 12th to 14th day after infection, the infected individuals developed high fever with malaise and signs of extreme exhaustion, headache, and backache. A maculopapular exanthema (macula) developed on the mucosae of the mouth and the pharynx which spread over the face and lower arms, then to the trunk and legs. Around the 8th to 9th day after occurrence of the rash, the exanthema developed into vesicles (papula) and pustules (pustula). The pustules were usually round and deeply embedded into the skin. Later, crusts (crusta) developed which healed during the phase of recovery leaving scars.

High numbers of virus particles were released into the saliva through the ulcerating lesions in the mouth and pharynx. Since this phenomenon occurred in the 1 st week of clinical disease, these patients were particularly infectious during this period. Part of the patients died around the 2 nd week of the disease by toxic reactions (cytokine storm), caused by circu- lating immune complexes and viral proteins. Encephalitis could occur as complication, but also as a rare adverse reaction to a vaccination with VACV, comparable with perivascular demyelinisation in serious courses of measles or chickenpox. Two forms of poxvirus infections showed usually a fatal outcome: haemorrhagic and malignant smallpox. Whether this is due to differences in the virulence of VARV strains is unclear.

\section{Monkeypox Virus (MPXV)}

Since the eradication of human smallpox, monkeypox are the most significant OPV infection in humans. Monkeypox was first observed in 1958 in experimental monkeys in Copenhagen [22], and infections in humans were first described in 1970. Monkeypox have up to now been a rare, sporadically occurring disease in humans. African gophers and rodents are considered as reservoir for this OPV species; monkeypox thus represent a zoonosis [23, 24].

The incubation period for monkeypox in humans is comparable to that of human pox (smallpox) with 10-14 days. The clinical pathology, too, resembles that of human pox. Infected individuals are infectious during the 1st week of occurrence of the erythema. As in human pox, around 2 days before the appearance of the skin rash, a prodromal phase starts with fever and malaise. Contrary to human pox, a pronounced unilateral or bilateral lymphadenopathy is observed in the majority of patients with MPXV infection, which may affect a variety of lymph nodes. The further course is similar to that of human pox, with the typical erythema spreading centrifugally. Up to now, no haemorrhagic courses have been observed in monkeypox infections [24, 25].

\section{Cowpox Infections (Cowpox Virus, CPXV)}

Infections of humans in most cases occur via skin lesions or by direct contact with infectious tissue or secretions from cats or infected rats [26-29]. Papules form at the infection site after 7-12 days which develop into vesicles and then painful haemorrhagic pustules and black crusts, frequently on the hands, shoulders, or in the face. Infected patients show influenza-like symptoms, nausea, and muscle pain. Although lesions are generally limited to the site of infection, severe courses have been reported requiring hospitalisation of the patient $[27,30]$. Infections have also been reported in the region of the eyes which were probably caused by smear infection. In many infections only lymphadenopathy is observed in the regional lymph nodes. After 6-8 weeks, the pustules/crusts dry up leaving scars in some cases.

In some patients infected with CPXV, although only local symptoms were observed, viraemia could be detected by quantitative PCR in the blood. This was unexpected, since no viraemic phase was observed in individuals with local reactions after a VACV vaccination [31].

However, generalised exanthema and severe systemic disease with fatal outcome can occur in immunosuppressed 
patients and patients with an impaired cellular immune response. These symptoms are similar to that of a VARV infection. In Germany one fatality occurred in 1991 in an asthma patient under immunosuppressive treatment $[32,33]$.

\section{Vaccinea Virus}

VACV were used by the WHO $[4,34]$ as vaccination viruses as human smallpox prophylaxis world-wide and during the eradication campaign up to the time of eradication of human smallpox. As a rule, the vaccination causes local reactions which can also be regarded as a marker for a successful vaccination. However, in rare cases, significant adverse reactions can occur, e.g. generalised vaccinia, bacterial contamination with subsequent bacterial infections, eczema vaccinatum as well as vaccinia gangraenosum. Vaccination encephalitis (1 in $100,000)$ or fatalities ( 1 in 1 million) can also occur in very rare cases. In connection with the vaccination, the issue of viraemia is discussed controversially. While some research groups claim that virus genome in the blood is detectable only in vaccinees with considerable adverse effects, others report that viral genomes, by means of very sensitive detection methods (PCR), could be identified in a part of the vaccinees up to 3 weeks after vaccination, but no infectious virus could be isolated $[35,36]$.

Due to the considerable adverse reactions known to be caused by the classical vaccines, efforts were stepped up after September 11, 2001 to develop attenuated VACV, e.g. modified vaccinia virus Ankara (MVA) and LC16m8. These so-called vaccines of the third generation can induce a good immune response, and achieve high protection in animal experiments against highly pathogenic OPV. On the other hand, adverse effects of conventional vaccines can be widely ruled out [37-42]. In Japan, LC16m8 has recently obtained a marketing authorisation as vaccine from the national authority.

\section{Diseases Caused by Other Poxvirus Species}

As a rule, infections with other poxviruses are of benign outcome, and clinical symptoms remain limited to the infection site. For practical reasons, we will address these diseases briefly in the epidemiological part of this article.

\subsection{Epidemiology}

\section{VARV}

The infection chain of pox virus is essentially maintained by transmissions from human to human. The main transmission media are droplets and aerosols, which are expectorated by individuals shortly before the symptomatic phase. Contaminated clothing and bed linen have partly contributed to the dissemination of the pathogenic agent.

A distinction between the two forms of the disease, variola major and variola minor, was only performed using epidemio- logical data during outbreaks of the disease. Variola minor (Alastrim) was observed for the first time in South Africa as late as the end of the 19th century, appeared in Florida later, and then spread to the USA, Latin America and Europe. The course of the variola minor infection was mild, and the fatality rate was indicated as $1 \%$ or lower. Typical human pox, variola major, however, has been known for several thousand years in Asia, and usually took a severe course with a fatality rate of around $30 \%$. In Europe, evidence of smallpox virus epidemics has been historically established for the first time around the 6th century. It must be noted that, compared with other virus infections such as measles or influenza, transmission of the smallpox agents only occurred when clinical symptoms appeared (around 14-17 days following infection). Consequently, in a lot of cases, only the members of a household, caregivers, or other persons in close contact with the smallpox patients were affected.

The last case of natural smallpox infection was reported from Somalia in 1977. In 1978, the infection of a woman photographer in Birmingham who was working at an institute performing smallpox research, which took a fatal course, was a cause of concern $[2,3]$. This patient also transmitted the disease to her mother. The route of infection of the photographer could not be established with certainty.

Considering the danger that VARV infections might take place in laboratories and might even be transmitted from these laboratories to the outside world, the WHO and all national authorities arranged for all poxviruses to be destroyed or to be transmitted to the collaboration centres designated by the WHO and located in the USA or the former USSR (now Russia) [43]. Since 1984, the remaining VARV isolates have been stored in 2 centres: in the Centres for Disease Control and Prevention (CDC) in Atlanta, GA, USA, and at the Research Institute of Viral Preparations in Moscow, from which the virus was transferred to the State Research Centre of Virology and Biotechnology (The Vector Institute) in Koltsovo (Region Novosibirsk, Russia) in 1994. As from the early 1990s, research projects with live viruses, variola genome, or variola genes have been evaluated by an expert committee of the WHO (WHO Advisory Committee on Variola Virus Research; www.who.int/csr/disease/smallpox/research/en/index.html), which recommends such projects, imposes conditions on them, or rejects them. One of the conditions is that only a maximum of $20 \%$ of the total genome may be used in scientific studies outside the Collaborating Centres at CDC (Atlanta, GA, USA) or at Vector (Koltsovo, Russia) www. who.int/csr/disease/smallpox/Summaryrecommendations May08.pdf).

Another condition is that the synthesis or any other type of production of more than 500 bases of a VARV sequence is not permitted without the authorisation from the WHO. In addition, such experiments must be strictly separated from experiments with other OPV species. 


\section{$M P X V$}

MPXV infections and minor outbreaks have been observed mainly in the tropical rain forests of Central Africa and West Africa (Sierra Leone, Central-African Republic of Congo, Liberia, Côte d'Ivoire, Cameroon, Nigeria, and Gabon). Major outbreaks have up to now only been described in the Democratic Republic of Congo. Epidemiological studies of MPXV infections in the 1980s showed a death rate of $17 \%$ for primary infections in humans and a transmission rate of $9 \%$ (secondary infections) $[44,45]$. The longest infection chain observed in this context comprised five [46] or six transmissions [47]. Sero-epidemiological studies point to the fact that in regions where MPXV infections occur, an increased seroprevalence against OPV is found which indicates that undetected infections take place with MPXV or other OPV.

In June 2003, MPXV infections in humans were diagnosed in the USA for the first time [48]. Animal traders imported MPXV from Gambia to the USA by infected African rodents, such as the Gambian rat (Cricetomyinae). In pet shops, the virus was then transmitted to prairie dogs. As a consequence of the animal trade, infected prairie dogs were spread over various different states where they infected more than 70 persons (animal carers and buyers). The course of the infection was relatively mild compared with infections with MPXV in Africa, and all infected individuals recovered which is considered as an indicator that different virus strains exist with different degrees of virulence.

In Europe (Netherlands, Denmark, France), the MPXV was observed exclusively in imported monkeys [49].

\section{$C P X V$}

This virus has so far been identified only in Europe and the neighbouring West Asian countries but also in Egypt [50, 51]. Rodents, such as mice, root voles and rats, serve as reservoir. CPXV were a problem in dairy farming for a long time. Since lesions mainly occurred in the teats, the agent rapidly spread among the livestock of one farm by milking. However, in Germany and other European countries, no CPXV infections have been described in cattle in the past few decades [31]. Instead, to an increasing extent CPXV infections have been observed in cats that may also transmit the virus to humans. This is why the agent is also called 'catpox' virus [52]. Cats probably become infected when hunting and feeding (infected) mice. A case of transmission from a rat to a girl has also been reported from the Netherlands, and recently, several transmissions could be detected by rats kept as pets to their owners, among other countries in Germany and France (http:// hygimia69.blogspot.com/2009/02/ecdc-risk-assessmentcowpox-in-germany.html) [53-55].

CPXV has a broad host spectrum, and lethal CPXV infections were observed in a number of animals. Besides the above-described animal species, outbreaks have been described in zoological gardens, affecting a great number of different animal species, including big cats and other felines, elephants, rhinoceroses, okapi and anteaters $[29,56]$. In addition, transmissions of CPXV to old world monkeys and new world monkeys in outdoor enclosures have been reported [57, 58]. In all cases, direct or indirect contact of the primates with rodents is assumed to be the source of infection.

The genetic analysis of CPXV shows that, unlike VARV, MPXV, camelpox virus (CMXV) and mousepox virus (ETCV), these viruses do not represent a closely related species but show high genetic variability for OPV and can be grouped into various different phylogenetically separated genotypes. It is noteworthy that this classification partly depends on the analysed genome region [57, 59, 60]. Up to now, there are no comparative studies on the pathogenic potential of the various CPXV isolates; the high variability of the CPXV and the high frequency of CPXV infections in different animal species raise the question to what extent differences in the pathogenicity of CPXV exist. In this context, it must be mentioned that CPXV isolated after an outbreak in new world monkeys in a zoo in Germany caused infections in marmosets (Callithrix jacchus) with lethal outcome, but did not seem to be pathogenic in mice $[57,61]$.

Cowpox, just as monkeypox, can be considered as an emerging or re-emerging disease; discussions are therefore underway that the increasing occurrence of these diseases justifies the development of safe OPV vaccines and chemotherapeutics.

The number of CPXV infections reported in humans has in fact risen in Germany in the past few years. It is, however, unclear whether this is based on increased awareness of the doctors or a decreasing immunity against the orthopox viruses after the vaccination against human smallpox was discontinued in the 1970s. The infection and the diagnosis of CPXV in humans are currently not notifiable.

\section{VACV and Related Agents}

VACV serves as prototype in the genus OPV and is used for the vaccination against human pox. VACV show a broad host spectrum and can infect a great variety of mammals, leading to severe diseases. Thus, it was reported that elephants in the zoo were infected by freshly vaccinated people. The origin of the VACV used for vaccination is unknown, and no animal reservoir could so far be described for these viruses. However, phylogenetic sequence analyses were able to show that VACV is closely related to other species of the OPV genus, such as horsepox virus (HSPV) and buffalopox virus (BPXV). Since it is less closely related to CPXV, it has been discussed whether the horsepox virus represents the origin of the VACVs.

VACV and its derivatives are not only used for vaccinations against VARV but also serve as vector in molecular biology and as starting material for the development of modern vaccines against infectious agents as well as in cancer therapy [62-64]. Laboratory infections with VACV in non-immunised individuals have been reported occasionally $[65,66]$. 


\section{VACV-Like Viruses}

These viruses present a health problem, especially in India and Brazil, not only in agriculture, but also for people who come into close contact with buffaloes and dairy cows. In Brazil, an increasing number of infections with VACV-like isolates has been observed in the past few decades in dairy cows as well as milkers and farmers [67, 68], which especially in dairy farming presents a considerable problem both for those affected and for the environment. Infected individuals develop skin lesions in the form of vesicles, predominantly on the hands, arms and face, as well as erythema. Other clinical signs include fever, headache, sweating, and enlarged axillary lymph nodes [69]. Clinical symptoms indicate that at least a part of the patients go through a viraemic phase.

VACV-like viruses were isolated as early as the 1960s. Today, they are characterised as pathogenic agents with considerable zoonotic potential $[67,68,70,71]$. The Brazilian isolates were grouped into the genus Orthopoxvirus under the species names BRZ-VACV or BR-VACV. Phylogenetic analyses show that these Brazilian isolates can be subdivided into two clearly distinguishable clades. Rodents are considered as reservoir for these pathogenic agents, as comparable viruses could be isolated from rats and mice, and a high seroprevalence could be determined in rodents. The origin of BRZ$\mathrm{VACV}$, however, is unknown and is under discussion. On the one hand, the close phylogenetic relationship between the isolates and VACV points to the fact that BRZ-VACV are VACV which spread throughout the country, for example in the rodent population. However, it is unclear when VACV was introduced into the rodent population and if multiple entries occurred. It was speculated that the first vaccine viruses which were brought at the beginning of the 19th century from Portugal to Brazil by slaves by arm-to-arm inoculation were transmitted unintentionally to animals, just like the additional VACV isolates which were imported to Brazil later. This could explain why phylogenetically distinct BRZ-VACV isolates are circulating in Brazil [67].

BPXV was first described in 1934. Outbreaks in animals and humans due to infections by BPXV have been reported from regions in which the Asian buffalo (Bubalus bubalis) is kept as dairy cattle, such as India, Pakistan, Indonesia, and Egypt, especially since the eradication of human pox [72]. BPXV presents a major problem for the milk-producing industry. Humans can become infected by contact with diseased animals. The symptoms are comparable to those of infections with CPXV. However, BPXV is closely related to VACV, and it has been suggested to classify BPXV as a clade within the species of VACV. It has been assumed that buffaloes became infected by VACV-vaccinated humans and that the virus has ever since been circulating in the buffalo population. On the other hand, it has also been suggested that original BPXV exist which are closely related to VACV $[72,73]$.

Recently, nosocomial infections with BPXV have been reported from Pakistan. On the one hand, this can be attributed to the high stability of the pathogen, on the other hand, however, it also proves the possibility of a transmission from human to human [74].

Phylogenetic studies on a HSPV isolate from Mongolia showed that HSPV and VACV were closely related. It has therefore been discussed whether VACV, which is used for the vaccination of humans, was originally a HSPV rather than a poxvirus originating from cattle $[75,76]$.

Rabbitpox virus (RPV) was isolated from diseased animals in a rabbit breeding farm in the Netherlands and could possibly serve as animal model for human pox [77]. RPV is phylogenetically closely related to $\mathrm{VACV}$, and it is therefore discussed that the poxvirus isolate from rabbit could be due to an unintentional transmission of VACV to laboratory animals [78].

\section{Parapox Virus}

Parapox virus (PPV) causes clinical signs in humans not distinguishable from local OPV infection. The Orf virus of the sheep and the goat is the prototype in the genus PPV; the bovine stomatitis virus and the pseudo-cowpox virus (milker's nodule) are transmitted to humans by direct contact with infected cattle $[75,79]$. There are no reliable data on the dissemination of PPV. Outbreaks in sheep and goats have been reported world-wide. Infection of humans occurs via skin lesions during contact with infected animals. After 3-7 days, papules form, usually on the hands, followed by vesicles, and finally wart-like nodules which subside after 3-4 weeks. The differentiation between PPV and OPV can be performed using the electron microscope (fig. 1). Molecular nucleic acid detection methods were developed for the diagnostics and differentiation of PPV and OPV infections [80-82]. PPV has been isolated from other animal species: red deer in New Zealand, Finnish reindeer, squirrels in the UK, and seals in the North Sea.

Molluscum contagiosum virus (MOCV) occurs world-wide. It manifests itself as self-limiting proliferations of the epidermis in the form of small bright-red bead-like nodules on all parts of the body. MOCV infects exclusively humans. Infections are observed most frequently in the autumn and spring. Usually children are affected. Transmission occurs by direct contact or indirectly by contaminated materials. In young adults, transmission can take place by sexual contact. In principle, MOCV induces a life-long immunity which, however, can be interrupted by immunosuppression. This means that immunosuppressed and HIV-infected individuals are affected more frequently by symptomatic MOCV infections [83-85]. A diagnosis is usually made clinically and histologically. In the electron microscope, MOCV can be morphologically differentiated from other poxviruses and herpes viruses (fig. 1). PCR and sequence analysis can be used for a differential diagnosis and genetic subtyping $[81,86]$.

Yaba monkey tumour virus (YMTV) and tanapox virus (TANV) represent a separate genus in the poxvirus family 
and are grouped in the genus Yatapox. Their area of geographical distribution is Central Africa [87-89]. Both viruses have a comparable host range and can only be propagated on primate cells [88]. Infections with TANV can take a course similar to that of a mild MPXV-like infection of primates including humans [90]. Occasionally, TANV causes infections in humans, and it is assumed that transmission is caused by insect bites. Infections in travellers have been reported [91, 92]. No reports are available on infections with YMTV in humans. The YMTV reservoir is unknown.

\subsection{Detection Methods and Their Significance}

For poxviruses, diagnostics and differential diagnostics were originally performed by using clinical samples for inoculation of the chorioallantoic membrane (CAM) of embryonated hen's eggs. By means of the cultivability of the viruses on the CAM at distinct temperatures (ceiling temperature), the pox morphology, and histological examinations, various OPVs could be distinguished from each other, and, in particular, VARV could be distinguished from other OPVs and herpes viruses. This method was considered as the gold standard by WHO during the smallpox eradication phase. Today, OPV is as a rule cultivated in cell cultures, and inoculation on the CAM of fertilised eggs after 11-13 days of incubation is only used in specialised laboratories [81]. OPV-infected cells can be identified by means of antibodies against VACV antigens in immunofluorescence assays or by immunohistological staining.

\section{Electron Microscopy}

With the aid of negative staining of clinical samples, electron microscopy permits rapid morphological differentiation of viruses of the OPV genus from other pathogens such as PPV and herpes viruses, but also bacteria such as Bacillus anthracis, which can cause comparable lesions such as pustules, vesicles, or crusts on the skin and therefore permits a differential diagnosis (fig. 1). Electron microscopy diagnostics is therefore suitable for rapid primary diagnostics permitting a first morphological characterisation of pathogens (diagnostics of the open view [93, 94]). In 'negative staining', OPV particles are brick-shaped, whereas PPV are ovoid. Both genera show characteristic surface structures (fig. 1). A morphological differentiation of MOCV from OPV is possible in experienced electron microscopy laboratories (fig. 1). A differentiation of species within the OPV genus is not possible by electron microscopy, since all OPV show the same morphological characteristics [81, 93, 95].

\section{Serology}

An OPV infection can be diagnosed with the aid of serological test methods. In this context ELISA and immunofluorescence methods have proved to be suitable methods. The de- tection of OPV-specific IgM is an indication of acute OPV infection which can be further confirmed by a second serum drawn after an interval of 10-14 days [75, 81]. The immune response against different OPV species cannot (up to now) be differentiated routinely due to the fact that the antigens are closely related within the genus. Differentiation is possible to a limited extent by complex and time-consuming pre-adsorption procedures performed on sera with antigen preparations of different OPV species and subsequent examination for reactivity in ELISA or immunofluorescence tests [96, 97].

Differentiation of neutralising antibodies against different OPV species is not possible due to the close antigenic relationship. However, the neutralisation test - using VACV as target virus in the plaque reduction test - is used to follow up the immune response after a vaccination and to determine the immune status, i.e. to confirm antibody titres in serology.

\section{Antigen Detection}

The detection of OPV antigens, for example in clinical samples (such as pustules, vesicles, and crusts), is possible by means of antigen capture ELISA in some specialised laboratories [75, 81]. Kitamoto and co-workers [98] used monoclonal antibodies in the immunoblot for the detection of OPV antigens. Antigen detection tests are less sensitive than PCR and, in addition, do not permit differentiation of the OPV species.

\section{Cell Culture}

OPV can be cultured in suitable cell cultures (generally monkey cells or human cells) from clinical samples of infected humans. In the cell culture, infected cells can be identified using characterised polyclonal and/or OPV-specific monoclonal antibodies [75, 81, 98]. After starting the culture, a differentiation of the virus species can be performed by PCR, and phylogenetic characterisation of the isolates can be carried out by sequence analysis $[80,81]$.

\section{Detection by Nucleic Acid Test (NAT)}

Polymerase chain reaction (PCR) methods have proved to be particularly suitable for the identification and differentiation of OPV species and for differential diagnostics of Poxviridae (e.g. OPV, PPV and MOCV) and other viruses such as varicella zoster (VZV) and herpes simplex virus (HSV), but also of bacteria such as Bacillus anthracis [81].

PCR tests in combination with restriction fragment length analysis permitted differentiation of OPV [99]. In recent years, various groups have published real-time PCR methods which permit an identification of OPV and differentiation of the species [reviewed in 80,81 ].

Because of the high hazard represented by human pox for the human population, special requirements are requested for specificity and sensitivity of the diagnostic methods. According to the present state of the art, OPV species are differentiated using suitable nucleic acid detection methods including phylogenetic analysis. The close genetic relation of OPV re- 
quires a particularly careful validation of the detection methods. In the literature, various PCR and real-time PCR methods are described permitting a reliable detection of VARV [reviewed in 80,81]. Real-time PCR on the one hand permits quantification of viral genomes; on the other hand, using suitable probes, melting curve analyses can be carried out, permitting a differentiation between OPV species or, in the case of suspected VARV genomes in clinical and environmental samples, excluding or confirming this virus [80, 81, $100,101]$. In principle, it is recommended to investigate several genome regions by the molecular detection methods and to perform phylogenetic analysis following sequencing of particular genome regions in order to achieve reliable classification of the viruses.

The isolation of poxvirus in clinical samples can be useful for molecular epidemiology or forensic investigations. However, for the assessment of the risk of infection by contaminated environmental samples, isolation is requested to prove the presence of infectious virus [102].

In the case of symptoms on the skin pointing to a poxvirus infection, the suspected diagnosis (OPV infections like cowpox, monkeypox, parapox, molluscum contagiosum, cutaneous anthrax, mycoses, Bartonella henselae) can be verified by means of virological or microbiological and molecular methods. Molecular detection methods (PCR, real-time PCR) are used in specialised laboratories to an increasing extent in diagnostics and differential diagnostics [81].

\section{Blood and Plasma Donors}

\subsection{Prevalence and Incidence of Poxvirus Infections in Donor Populations}

There are no reliable data on the seroprevalence of OPV in Germany, neither in humans nor in the animal population [103, 104]. Compulsory smallpox vaccinations were discontinued in the Federal Republic of Germany in 1977, and in the German Democratic Republic in 1980. It can therefore be assumed that the portion of immunologically naïve persons in the population has been on the increase. In Germany, in recent years people have been vaccinated with VACV Lister-Elstree, but only to a very limited extent in vaccination studies.

In Germany and other countries, infections with MOCV as a rule occur in children and immunosuppressed individuals. Studies on the prevalence of PPV have so far not been performed.

\subsection{Definition of Exclusion Criteria}

In principle, the general guidelines of the Bundesärztekammer (German Medical Association) and the Paul-EhrlichInstitut $[105,106]$ apply to the determination of exclusion cri- teria for blood donors. These guidelines do not lay down any specific exclusion criteria for smallpox infections, since human pox are considered as eradicated. Other poxvirus infections manifest themselves as local skin lesions, are accompanied by fever and malaise, and would be captured through the usual exclusion criteria for blood donors.

\subsection{Donor Testing and Significance}

In principle, donor testing for OPV genome is possible by means of PCR or antibody detection ( $\operatorname{IgM}$ or $\operatorname{IgG}$ ). In conformity with the data on the epidemiology of OPV infections in Germany, donor testing is regarded as not necessary.

\subsection{Donor Interviews}

Individuals willing to donate blood are interviewed on febrile infections in the history in compliance with the guidelines of the Bundesärztekammer and the Paul-Ehrlich-Institut [105, 106].

\subsection{Donor Information and Counselling}

Since no specific examination for OPV markers is performed, no meaningful OPV-specific donor information is possible.

\section{Recipient}

\subsection{Prevalence and Incidence of Blood-Associated Infections and Infectious Diseases in Recipient Populations}

Neither donor- nor recipient-specific information is available in Germany on the prevalence and incidence of OPV infections. Because vaccinations against smallpox became compulsory in the Deutsche Reich (German Empire) in 1874 and was continued up to 1976 (Federal Republic) and 1980 (German Democratic Republic), it can be assumed that the majority of individuals for whom these compulsory vaccinations applied still have residual antibodies against OPV. The portion of the population that acquired an immune response to cowpox or catpox virus or other OPVs after compulsory vaccination has so far not been sufficiently studied.

\subsection{Immune Status (Resistance, Existing Immunity, Immune Response, Age, Exogenous Factors)}

No data are available on the serostatus of the recipients of blood and blood products in Germany. Studies in various countries showed that people who had been vaccinated before 
the vaccination was discontinued after the eradication of human pox partly revealed antibodies against VACV. Epidemiological studies had shown that 3 years after vaccination, $90 \%$ of the vaccinees had sufficient protection which thereafter decreased over the years. An infection with human poxvirus, however, generally took a mild course in these people. It is currently discussed to what extent people who in former times received a vaccination are still protected against OPV infections [107-109].

\subsection{Severity and Course of the Disease}

Up to now, no reports are available on infections with OPV or other human pathogenic poxviruses by transfusions.

\subsection{Therapy and Prophylaxis}

\section{Vaccination}

A prophylactic vaccination against OPV is possible today, too, using the previously authorised VACV vaccines as well as those currently being developed. Because of the considerable adverse reactions, no vaccinations have been performed in Germany, unlike the USA, where certain populations (army members, members of the health service, etc.) were vaccinated with VACV after September 11, 2001 [107]. It remains to be seen, when and to what extent new vaccines on the basis of further attenuated VACV, such as MVA or the Japanese vaccine strain LC16m8 which are considered as vaccines of the third generation, will replace vaccines used for the eradication or vaccines of the second generation. It must be noted that LC16m8 was licensed as vaccine in Japan. The extent to which MVA or derivatives of MVA will be licensed for prophylactic vaccination of humans also remains to be seen $[39,42,110]$. In this context, the clinical trial of the MVA vaccine IMVAMUNE in the USA has made the most progress [41, 111].

New data from various animal models allow to conclude that an effective protection against OPV infections can be achieved by MVA immunisation and may even be effective following exposure with pathogenic OPV [109, 112].

\section{Chemotherapy}

The efforts to develop new chemotherapeuticals were increased especially with regard to potential bioterrorist attacks with VARV. Cidofovir is an acyclical nucleoside phosphate which inhibits the DNA polymerase of various DNA viruses. It is used for the therapy of CMV infections, in particular in CMV retinitis of HIV-infected individuals but inhibits also the replication of OPV $[9,113]$. However, due to the fact that it has to be administered i.v. and due to its major adverse reactions (kidney toxicity), cidofovir can only be used to a limited extent. Hexadecyloxypropylcidofovir (CMX001), a derivative of cidofovir, is bioavailable after oral administration.
ST246 is a small molecule compound which specifically interacts with an OPV envelope protein (F13L protein) and is thus able to inhibit the exit of OPV from infected cells [114]. In animal experiments, the treatment with ST246 even proved to be effective after the manifestation of clinical symptoms [115]. In addition, experimental systems were able to show that the vaccination with concomitant administration of ST246 induced a cellular and a humoral immune response so that the mice were protected against a challenge with pathogenic VACV [116].

ST246 was used successfully for the treatment of a 28-month-old infant who had been infected with VACV by his vaccinated father and developed severe eczema vaccinatum [117]. In combination with ST246, CMX001 displayed a synergistic effect in the treatment of experimental OPV infections [118].

\section{Passive Immunisation}

Passive immunisation with immunoglobulin preparations (vaccinia IgG; VIG) has so far been recommended only in the case of an occurrence of vaccination-associated complications. However, VIG products are available only to a very limited extent world-wide.

\subsection{Transmissibility}

No reports are available on the transmission of OPV by blood or blood products.

\subsection{Frequency of Administration and Type and Amount of Blood Products}

Because of the inactivation or removal of OPV during the manufacture of plasma products, there is no risk of transmission by these products. No transmissions by cellular blood products have so far been reported. It can be assumed that the potential risk of a transmission in the viraemic phase is largely reduced for leucocyte-depleted cellular blood products, since CPXV and MPXV circulate in the blood in a cell-associated manner.

\section{Blood Products}

\subsection{Infectious Load of the Starting Material and Test Methods}

So far, there are no studies on the OPV load of the starting material. Studies on healthy VACV-immunised individuals show that VACV can be detected neither in the plasma nor associated with cells after vaccination with live virus. In patients with severe clinical symptoms after vaccination with VACV, virus could be detected in the cells, but not in plasma. 
Two proliferation phases are observed in classical generalised poxvirus infections in humans or animals (VARV, ECTV, CMXV); the first one is lymphogenic and occurs after replication at the infection site and/or infection of the draining lymph node with the dissemination to the internal lymphatic tissues. The second viraemic phase leads to infection of skin and mucosae as well as other organs via the blood. Concerning the infection with VARV, infectious viruses could be detected in the blood of infected individuals [119]. A systemic infection following an infection with other OPV, however, is not regularly observed. Efforts to detect MPXV in the blood of infected individuals are not always successful, and viraemia probably depends on the severity of the disease $[47,120]$.

Investigations on the dissemination of VACV following immunisation in the blood is discussed controversially $[5,36$, 121]. In some studies, viraemia was detected by PCR up to 21 days following an immunisation [3]. Other authors did not succeed in detecting VACV DNA in the blood, or did so only in isolated cases, and even then, only in a short time interval after the vaccination $[36,122,123]$. Infectious virus could not be detected in these investigations. It must therefore be assumed that viral DNA exists only cell-bound. In cases where the vaccination showed considerable adverse effects, viraemia could usually be detected by PCR [124, $125]$.

Nitsche and co-workers [126] have recently been able to show that virus DNA can be detected in blood also in CPXV infections and that the genome detection is possible only in the cellular fraction of the blood.

Since according to the current state of knowledge OPV occur cell-bound in the blood also in the viraemic phase, an examination of cell-containing materials for OPV genome by NAT would be possible [100, 126, 127].

\subsection{Methods for Removal and Inactivation of the Infectious Agent}

As far as the manufacture of plasma products is concerned, ways of inactivation or removal generally are simpler for enveloped, lipid-containing viruses than for non-enveloped viruses. For filtration methods (virus filter, nanofilter), it can be assumed that these remove OPV effectively due to the size of virus particles. In urokinase preparations, gamma irradiation with $50 \mathrm{kGy}$ reduced VACV by more than $7.7 \log _{10}[128]$.

\subsection{Feasibility and Validation of Procedures for Removal/ Inactivation of the Infectious Agent}

Examinations of the removal and inactivation of OPV in blood products were performed within model studies on the virus safety of blood products. Various methods were evaluated by Remington and co-workers [129] in extensive studies on virus safety of plasma products. In stabilised alpha1proteinase inhibitor products $(0.38 \%$ citrate, $37 \%$ sucrose $)$, the titre of VACV was reduced by approximately the factor of $10^{2}$ after pasteurisation for $1 \mathrm{~h}$ at $60{ }^{\circ} \mathrm{C}$, and after $3 \mathrm{~h}$ infectious virus titres fell below the detection limit (reduction factor $\left.\geq 10^{5}\right)$. In non-stabilised human plasma protein solution, the titre of VACV was no longer detectable after $2 \mathrm{~h}$ at $60{ }^{\circ} \mathrm{C}$ (reduction factor $\geq 10^{5}$ ). In studies on the stability of VACV in solvent/detergent (S/D) procedures for the preparation of virus-safe anti-haemophilic factor (AHF) by treatment with $0.3 \%$ TNPB / $1 \%$ Tween 80 or $0.15 \%$ TNPB / $0.5 \%$ Tween 80 , the titre was reduced only by a factor of $10^{3}$ after $6 \mathrm{~h}$ of treatment. In inactivation experiments using $0.3 \%$ TNPB / 0.2\% cholate, VACV was reduced by more than a factor of $10^{4}$ within $30 \mathrm{~min}$, and no infectious virus was detectable after $3 \mathrm{~h}$ of treatment. Studies by Roberts [130] showed that, compared with other enveloped viruses, VACV showed a higher resistance when treated with $\mathrm{S} / \mathrm{D}$. Treatment of immunoglobulin products with $20 \mathrm{mmol} / \mathrm{l}$ sodium caprylate led to a reduction of the VACV titre below the detection limit (reduction factor $\geq 10^{6}$ ) within $3 \mathrm{~min}$. It could be shown in various experiments that poxviruses could be effectively removed from plasma products by filtration $[131,132]$. In conclusion, various elimination and inactivation methods are available for the production of OPV-safe plasma products. A risk of transmission of OPV by plasma products is therefore not recognisable.

The effectiveness of inactivation methods developed for plasma and cellular blood products (e.g. treatment with amotosalen, riboflavin, or methylene blue) is currently unknown. Since, according to the current state of knowledge, OPV in blood is cell-bound, it must be assumed that leucocyte depletion leads to a considerable reduction of the risk of the transmission of OPV.

\section{Assessment}

As various studies have shown, viraemia can be observed in infections with viruses from the OPV group, such as MPXV and CPXV, as well as in individuals vaccinated with VACV. Thus, OPV genomes could be found in the cell-containing fraction of the blood up to 3 weeks after the onset of clinical symptoms. In contrast to VARV infections, however, no infectious virus could be isolated from blood. In principle, viraemic blood donations can be detected by using NAT methods.

Infections with MPXV in humans have been observed. In the past few years, an increasing number of infections with CPXV in humans has been observed in Germany, which partly took courses with serious clinical symptoms. The genetic differences observed in the CPXV isolates and the dif- 
ferent clinical courses give rise to the assumption that CPXV can be to a variable extent pathogenic in humans. It seems necessary to monitor the epidemiological situation of OPV and in particular CPXV infections. Studies in molecular biology may provide information on previously unknown OPV variants displaying a modified pathological potential.

However, infections with OPV currently do not present a recognisable risk for the blood donation system in Germany. OPV in plasma derivatives are eliminated and/or inactivated by the manufacturing procedure so that these products are safe.

If a vaccination against OPV should become necessary, a deferral of 4 weeks after immunisation with live vaccine should be sufficient.
This paper was completed on October 7, 2009, and approved by the German Advisory Committee Blood (Arbeitskreis Blut) on June 7, 2010. It was compiled by the members of the subgroup 'Assessment of Pathogens Transmissible by Blood' of the German Advisory Committee Blood (Arbeitskreis Blut):

Prof. Dr. Georg Pauli

Dr. Johannes Blümel

Prof. Dr. Reinhard Burger

Prof. Dr. Christian Drosten

Dr. Albrecht Gröner

Prof. Dr. Lutz Gürtler

Dr. Margarethe Heiden

Prof. Dr. Martin Hildebrandt

Prof. Dr. Dr. Bernd Jansen

Dr. Thomas Montag-Lessing

Dr. Ruth Offergeld

Prof. Dr. Rainer Seitz

Dr. Uwe Schlenkrich

Dr. Volkmar Schottstedt

Dr. Johanna Strobel

Dr. Hannelore Willkommen

Prof. Dr. Carl-Heinz Wirsing von König

\section{References}

1 Ladnyi ID, Breman JG: Smallpox eradication: progress and problems. Dev Biol Stand 1978;41: 281-290.

2 Anonymous: Smallpox in Birmingham. Br Med J 1978;2(6140):837.

3 Geddes AM: The history of smallpox. Clin Dermatol 2006;24:152-157.

4 WHO Global Commission for the Certification of Smallpox Eradication (ed.): The Global Eradication of Smallpox. Final Report of the Global Commission for the Certification of Smallpox Eradication, Geneva, 1979. Geneva, WHO, 1980.

5 Fenner F, Henderson DA, Arita I, Jezek Z, Ladnyi ID: Smallpox and Its Eradication - World Health Organisation 1988. http://whqlibdoc.who.int/smallpox/9241561106.pdf.

6 Moussatché N, Damaso CR, McFadden G: When good vaccines go wild: feral orthopoxvirus in developing countries and beyond. J Infect Developing Countries 2008;2:156-173.

7 Garon CF, Barbosa E, Moss B: Visualization of an inverted terminal repetition in vaccinia virus DNA. Proc Natl Acad Sci U S A 1978;75:4863-4867.

8 Moss B: Poxvirus entry and membrane fusion. Virology 2006;344:48-54.

$\checkmark 9$ Sliva K, Schnierle B: From actually toxic to highly specific - novel drugs against poxviruses. Virology J 2007;4:8.

10 Roberts KL, Smith GL: Vaccinia virus morphogenesis and dissemination. Trends Microbiol 2008; $16: 472-479$.

11 Seet BT, Johnston JB, Brunetti CR, Barrett JW, Everett H, Cameron C, Sypula J, Nazarian SH, Lucas A, McFadden G: Poxviruses and immune evasion. Annu Rev Immunol 2003;21:377-423.

12 Mahalingam S, Karupiah G: Modulation of chemokines by poxvirus infections. Curr Opin Immunol 2000;12:409-412.

13 Ambrose CT: Osler and the infected letter. Emerg Infect Dis 2005;11:689-693.

14 Harper GL: Airborne micro-organisms: survival test with four viruses. J Hyg 1961;59:479-486.
15 Sinclair R, Boone SA, Greenberg D, Keim P, Gerba CP: Persistence of category A select agents in the environment. Appl Environ Microbiol 2008;74: 555-563.

16 Huq F: Effect of temperature and relative humidity on variola virus crusts. Bull World Health Organ 1976;54:710-712.

17 Downie AW, Dumbell KR: Survival of variola virus in dried exudat and crusts from smallpox patients. Lancet 1947;i:550-553.

18 Wolff HL, Croon JJ: The survival of smallpox virus (variola minor) in natural circumstances. Bull World Health Organ 1968;38:492-493.

19 Tanabe I, Hotta S: Effect of disinfectants on variolavirus in cell culture. Appl Environ Microbiol 1976;32:209-212.

20 Lelie PN, Reesink HW, Lucas CJ: Inactivation of 12 viruses by heating steps applied during manufacture of a hepatitis B vaccine. J Med Virol 1987;23: 297-301.

21 Essbauer S, Meyer H, Porsch-Özcürümez M, Pfeffer M: Long-lasting stability of vaccinia virus (orthopoxvirus) in food and environmental samples. Zoonoses Public Health 2007;54:118-124.

22 von Magnus P, Anderson EK, Petersen KB, BirchAnderson A: A pox-like disease in cynomolgus monkeys. Acta Pathol Microbiol Scand 1959;46:156-176.

23 Di Giulio DB, Eckburg PB: Human monkeypox: an emerging zoonosis. Lancet Infect Dis 2004;4: 15-25.

24 Parker S, Nuara A, Buller RM, Schultz DA: Human monkeypox: an emerging zoonotic disease. Future Microbiol 2007;2:17-34.

25 Sbrana E, Xiao SY, Newman PC, Tesh RB: Comparative pathology of North American and central African strains of monkeypox virus in a ground squirrel model of the disease. Am J Trop Med Hyg 2007;76:155-164.

26 Eis-Hübinger AM, Gerritzen A, Schneweis KE, Pfeiff B, Pullmann H, Mayr A, Czerny CP: Fatal cowpox-like virus infection transmitted by cat. Lancet 1990;336(8719):880.
27 Baxby D, Bennett M, Getty B: Human cowpox 1969-93: a review based on 54 cases. Br J Dermatol 1994:131:598-607.

28 Wolfs TF, Wagenaar JA, Niesters HG, Osterhaus AD: Rat-to-human transmission of cowpox infection. Emerg Infect Dis 2002;8:1495-1496.

29 Kurth A, Wibbelt G, Gerber HP, Petschaelis A, Pauli G, Nitsche A: Rat-to-elephant-to-human transmission of cowpox virus. Emerg Infect Dis 2008;14:670-671.

30 Bonnekoh B, Falk K, Reckling KF, Kenklies S, Nitsche A, Ghebremedhin B, Pokrywka A, Franke I, Thriene B, König W, Pauli G, Gollnick H: Cowpox infection transmitted from a domestic cat. J Dtsch Dermatol Ges 2008;6:210-213.

31 Nitsche A, Pauli G: Sporadic human cases of cowpox in Germany. Euro Surveill 2007;12(4):E070419.3.

32 Czerny CP, Eis-Hübinger AM, Mayr A, Schneweis KE, Pfeiff B: Animal poxviruses transmitted from cat to man: current event with lethal end. Zentralbl Veterinarmed B 1991;38:421-431.

33 Pfeiff B, Pullmann H, Eis-Hübinger AM, Gerritzen A, Schneweis KE, Mayr A: Letale TierpockenInfektion bei einem Atopiker unter dem Bild einer Variola vera. Hautarzt 1991;42:293-297.

34 WHO: Declaration of global eradication of smallpox. Wkly Epidemiol Rec 1980;55:2127-2137.

35 Cummings JF, Polhemus ME, Hawkes C, Klote M, Ludwig GV, Wortmann G: Lack of vaccinia viremia after smallpox vaccination. Clin Infect Dis 2004;38:456-458.

36 Savona MR, Dela Cruz WP, Jones MS, Thornton JA, Xia D, Hadfield TL, Danaher PJ: Detection of vaccinia DNA in the blood following smallpox vaccination. JAMA 2006;295:1898-1900.

37 Morikawa S, Sakiyama T, Hasegawa H, Saijo M, Maeda A, Kurane I, Maeno G, Kimura J, Hirama C, Yoshida T, Asahi-Ozaki Y, Sata T, Kurata T, Kojima A: An attenuated LC16m8 smallpox vaccine: analysis of full-genome sequence and induction of immune protection. J Virol 2005;79:1187311891. 
38 Parrino J, Graham BS: Smallpox vaccines: past, present, and future. J Allergy Clin Immunol 2006; 118:1320-1326.

\39 Kenner J, Cameron F, Empig C, Jobes DV, Gurwith M: LC16m8: An attenuated smallpox vaccine. Vaccine 2006;24:7009-7022.

40 Frey EF, Newman FK, Kennedy JS, Sobek V, Ennis FA, Hill H, Yan LK, Chaplin P, Vollmar J, Chaitman BR, Belsheb RB: Clinical and immunologic responses to multiple doses of IMVAMUNE (modified vaccinia Ankara) followed by Dryvax challenge. Vaccine 2007;25:8562-8573.

41 Kennedy JS, Greenberg RN: IMVAMUNE ${ }^{\circledR}$ : modified vaccinia Ankara strain as an attenuated smallpox vaccine. Exp Rev Vaccines 2009;8:13-24

42 Saito T, Fujii T, Kanatani Y, Saijo M, Morikawa S, Yokote H, Takeuchi T, Kuwabara N: Clinical and immunological response to attenuated tissue-cultured smallpox vaccine LC16m8. JAMA 2009;301:1025-1033.

43 WHO: Smallpox eradication: destruction of variola virus stocks. Wkly Epidemiol Rec 2002;77(5):34-38.

44 Breman JG, Kalisa R, Steniowski MV, Zanotto E, Gromyko AI, Arita I: Human monkeypox, 197079. Bull World Health Organ 1980;58:165-182.

45 Jezek Z, Grab B, Szczeniowski MV, Paluku KM, Mutombo M: Human monkeypox: secondary attack rates. Bull World Health Organ 1988;66:465-470

46 Jezek Z, Arita I, Mutombo M, Dunn C, Nakano JH, Szczeniowski M: Four generations of probable person-to-person transmission of human monkeypox. Am J Epidemiol 1986;123:1004-1012.

47 Learned LA, Reynolds MG, Wassa DW, Li Y, Olson VA, Karem K, Stempora LL, Braden ZH, Kline R, Likos A, Libama F, Moudzeo H, Bolanda JD, Tarangonia P, Boumandoki P, Formenty P, Harvey JM, Damon IK: Extended interhuman transmission of monkeypox in a hospital community in the Republic of the Congo, 2003. Am J Trop Med Hyg 2005;73:428-434.

48 CDC, Centers for Disease Control and Prevention: Multistate outbreak of monkeypox - Illinois, Indiana, and Wisconsin, 2003. MMWR Morb Mortal Wkly Rep 2003;52:537-540.

49 Arita I, Gispen R, Kalter SS, Lim Teong Wah, Marennikova SS, Netter R, Tagaya I: Outbreaks of monkeypox and serological surveys in nonhuman primates. Bull World Health Organ 1972;46:625631.

50 Vorou RM, Papavassiliou VG, Pierroutsakos IN: Cowpox virus infection: an emerging health threat. Curr Opin Infect Dis 2008;21:153-156.

-51 Amer M, El-Gharib I, Rashed A, Farag F, Emara M: Human cowpox infection in Sharkia Governorate, Egypt. Int J Dermatol 2001;40:14-17.

52 Bennett M, Begon ME: Virus zoonoses--a longterm overview. Comp Immunol Microbiol Infect Dis 1997;20:101-109.

53 Ninove L, Domart Y, Vervel C, Voinot C, Salez N, Raoult D, Meyer H, Capek I, Zandotti C, Charrel $\mathrm{RN}$ : Cowpox virus transmission from pet rats to humans, France. Emerg Infect Dis 2009;15:781-784.

54 Kuczka A, Nitsche A, Höveler R, Becker C, Kurth A: Ein Bericht über durch Heimtierratten auf Menschen übertragene Kuhpockenvirusinfektion. Dtsch Tierärztebl 2009;3:316-319.

55 Becker C, Kurth A, Hessler F, Kramp H, Gokel M, Hoffmann R, Kuczka A, Nitsche A: Cowpox virus infection in pet rat owners - not always immediately recognized. Dtsch Ärztebl Int 2009;106:329_ 334.

56 Bennett M, Baxby D: Cowpox. J Med Microbiol 1996;45:157-158.
57 Mätz-Rensing K, Ellerbrok H, Ehlers B, Pauli G, Floto A, Alex M, Czerny CP, Kaup FJ: Fatal poxvirus outbreak in a colony of New World monkeys. Vet Pathol 2006;43:212-218

58 Martina BE, van Doornum G, Dorrestein GM, Niesters HG, Stittelaar KJ, Wolters MA, van Bolhuis HG, Osterhaus AD: Cowpox virus transmission from rats to monkeys, the Netherlands. Emerg Infect Dis 2006;12:1005-1007.

59 Gubser C, Hué S, Kellam P, Smith GL: Poxvirus genomes: a phylogenetic analysis. J Gen Virol 2004;85:105-117

60 Pelkonen PM, Tarvainen K, Hynninen A, Kallio ERK, Henttonen H, Palva A, Vaheri A, Vapalahti O: Cowpox with severe generalized eruption, Finland. Emerg Infect Dis 2003;9:1458-1461

61 Kramski M: Infections of common marmosets with calpox virus: a model for smallpox virus infections. Dissertation, Humboldt-Universität Berlin, 2009.

62 Drexler I, Staib C, Sutter G: Modified vaccinia virus Ankara as antigen delivery system: how can we best use its potential? Curr Opin Biotechnol 2004;15:506-512.

63 Shen Y, Nemunaitis J: Fighting cancer with vaccinia virus: teaching new tricks to an old dog. Mol Ther 2005;11:180-195.

64 Gómez CE, Nájera JL, Krupa M, Esteban M: The poxvirus vectors MVA and NYVAC as gene delivery systems for vaccination against infectious diseases and cancer. Curr Gene Ther 2008;8:97-120.

65 Wlodaver CG, Palumbo GJ, Waner JL: Laboratoryacquired vaccinia infection. J Clin Virol 2004;29: 167-170.

66 Lewis FM, Chernak E, Goldman E, Li Y, Karem K, Damon IK, Henkel R, Newbern EC, Ross P, Johnson CC: Ocular vaccinia infection in laboratory worker, Philadelphia, 2004. Emerg Infect Dis 2006;12:134-137. Available at www.cdc.gov/ncidod/ EID/vol12no01/05-1126.htm.

67 Trindade GS, Emerson GL, Carroll D, Kroon EG, Damon IK: Brazilian vaccinia viruses and their origins. Emerg Infect Dis 2007;13:965-972. Available at www.cdc.gov/EID/content/13/7/965.htm.

68 Drumond BP, Leite JA, da Fonseca FG, Bonjardim CA, Ferreira PC, Kroon EG: Brazilian vaccinia virus strains are genetically divergent and differ from the Lister vaccine strain. Microbes Infect 2008;10:185-197

69 Nagasse-Sugahara TK, Kisielius JJ, Ueda-Ito M, Curti SP, Figueiredo CA, Cruz AS, Silva MMMJ, Ramos CH, Silva MCC, Sakurai T, Salles-Gomes LF: Human vaccinia-like virus outbreaks in São Paulo and Goiás states, Brazil: virus detection, isolation and identification. Rev Inst Med Trop S Paulo 2004;46:315-322.

70 Damaso CR, Esposito JJ, Condit RC, Moussatche $\mathrm{N}$ : An emergent poxvirus from humans and cattle in Rio de Janeiro State: cantagalo virus may derive from Brazilian smallpox vaccine. Virology 2000;22: 439-449.

71 Leite JA, Drumond BP, Trindade GS, Lobato ZIP, da Fonseca FG, dos Santos JR, Madureira MC, Guedes MIMC, Ferreira JMS, Bonjardim CA, Ferreira PCP, Kroon EG: Passatempo virus, a Vaccinia virus strain, Brazil. Emerg Infect Dis 2005;11: 1935-1938.

72 Singh RK, Hosamani M, Balamurugan V, Bhanuprakash V, Rasool TJ, Yadav MP: Buffalopox: an emerging and re-emerging zoonosis. Anim Health Res Rev 2007;8:105-114.

73 Singh RK, Hosamani M, Balamurugan V, Satheesh CC, Rasool TJ, Yadav MP: Comparative sequence analysis of envelope protein genes of Indian buffalopox virus isolates. Arch Virol 2006;151:1995-2005.
4 Zafar A, Swanepoel R, Hewson R, Nizam M, Ahmed A, Husain A, Grobbelaar A, Bewley K, Mioulet V, Dowsett B, Easterbrook L, Hasan R: Nosocomial buffalopoxvirus infection, Karachi, Pakistan. Emerg Infect Dis 2007;13:902-904.

75 Essbauer S, Pfeffer M, Wilhelm S, Meyer H: Zoonotische Pockenviren. Bundesgesundheitsbl Gesundheitsforsch Gesundheitsschutz 2004;47:671-679.

76 Tulman ER, Delhon G, Afonso CL, Lu Z, Zsak L, Sandybaev NT, Kerembekova UZ, Zaitsev VL, Kutish GF, Rock DL: Genome of horsepox virus. J Virol 2006;80:9244-9258.

77 Adams MM, Rice AD, Moyer RW: Rabbitpox virus and vaccinia virus infection of rabbits as a model for human smallpox. J Virol 2007;81:1108411095.

78 Li G, Chen N, Roper RL, Feng Z, Hunter A, Danila M, Lefkowitz EJ, Buller RM, Upton C: Complete coding sequences of the rabbitpox virus genome. J Gen Virol 2005;86:2969-2977.

79 Büttner M, Rziha HJ: Parapoxviruses: From the lesion to the viral genome. J Vet Med B Infect Dis Vet Public Health 2002;49:7-16.

80 Pfeffer M, Meyer H: Poxvirus diagnostics; in Mercer AA, Schmidt A, Weber O (eds): Poxviruses. Basel, Birkhäuser, 2007, pp 355-373.

81 Kurth A, Nitsche A: Fast and reliable diagnostic methods for the detection of human poxvirus infections. Future Virol 2007;2:467-479.

82 Nitsche A, Büttner M, Wilhelm S, Pauli G, Meyer $\mathrm{H}$ : Real-time PCR detection of parapoxvirus DNA. Clin Chem 2006;52(2):316-319.

83 Braue A, Ross G, Varigos G, Kelly H: Epidemiology and impact of childhood molluscum contagiosum: a case series and critical review of the literature. Pediatr Dermatol 2005;22:287-294.

84 Brown J, Janninger CK, Schwartz RA, Siverberg NB: Childhood molluscum contagiosum. Int J Dermatol 2006;45:93-99.

85 Hanson D, Diven DG: Molluscum contagiosum. Dermatol Online J 2007;9(2):2.

86 Trama JP, Adelson ME, Mordechai E: Identification and genotyping of molluscum contagiosum virus from genital swab samples by real-time PCR and Pyrosequencing. J Clin Virol 2007;40:325-329.

87 Downie AW, España C: Comparison of tanapox virus and yaba-like viruses causing epidemic disease in monkeys. J Hyg (Lond) 1972;70:23-32.

88 Downie AW, España C: A comparative study of tanapox and yaba viruses. J Gen Virol 1973;19: $37-49$.

89 Jezek Z, Arita I, Szczeniowski M, Paluku KM, Ruti K, Nakano JH: Human tanapox in Zaire: clinical and epidemiological observations on cases confirmed by laboratory studies. Bull World Health Organ 1985;63:1027-1035.

90 Damon IK: Poxviruses; in Knipe, DM, Howley PM (eds): Fields Virology, vol. 2. 5th ed. Lippincott, New York, Williams and Wilkins, 2007, pp 2947-2976.

91 Stich A, Meyer H, Kohler B, Fleischer K: Tanapox first report in a European traveller and identification by PCR. Trans R Soc Trop Med Hyg 2002; 96:178-179.

92 Dhar AD, Werchniak AE, Li Y, Brennik JB, Goldsmith CS, Kline R, Damon I, Klaus SN: Tanapox infection in a college student. N Engl J Med 2004; 350:361-366.

93 Biel SS, Gelderblom HR: Electron microscopy of viruses; in Cann AJ (ed): Cell Culture - a Practical Approach. Oxford, Oxford University Press, 1999, pp 111-147.

94 Gelderblom HR, Renz H, Özel M: Negative staining in diagnostic virology. Micron Microsc Acta 1991;22:435-447. 
95 Curry A, Appleton H, Dowsett B: Application of transmission electron microscopy to the clinical study of viral and bacterial infections: present and future. Micron 2006;37:91-106.

96 Goldberg TL, Chapman CA, Cameron K, Saj T, Karesh WB, Wolfe ND, Wong SW, Dubois ME, Slifka MK: Serologic evidence for novel poxvirus in endangered red Colobus monkeys, Western Uganda. Emerg Infect Dis 2008;14:801-803.

97 Dubois ME, Slifka MK: Retrospective analysis of monkeypox infection. Emerg Infect Dis 2008;14: 592-599.

98 Kitamoto N, Kobayashi T, Kato Y, Wakamiya N, Ikuta K, Tanaka T, Ueda S, Miyamoto H, Kato S: Preparation of monoclonal antibodies crossreactive with orthopoxviruses and their application for direct immunofluorescence test. Microbiol Immunol 2005;49:219-225

-99 Esposito JJ, Knight JC: Orthopoxvirus DNA: a comparison of restriction profiles and maps. $\mathrm{Vi}$ rology 1985;143:230-251.

100 Nitsche A, Ellerbrok H, Pauli G: Detection of orthopoxvirus DNA by real-time PCR and identification of variola virus DNA by melting analysis. J Clin Microbiol 2004;42:1207-1213.

-101 Olson VA, Laue T, Laker MT, Babkin IV, Drosten C, Shchelkunov SN, Niedrig M, Damon IK, Meyer H: Real-time PCR system for detection of orthopoxviruses and simultaneous identification of smallpox virus. J Clin Microbiol 2004;42: 1940-1946.

102 Nitsche A, Stern D, Ellerbrok H, Pauli G: Detection of infectious poxvirus particles. Emerg Infect Dis 2006;12(7):1139-1141.

103 Czerny CP, Wagner K, Gessler K, Mayr A, Kaaden OR: A monoclonal blocking-ELISA for detection of orthopoxvirus antibodies in feline sera. Vet Microbiol 1996;52:185-200.

104 Meyer H, Schay C, Mahnel H, Pfeffer M: Characterization of orthopoxviruses isolated from man and animals in Germany. Arch Virol 1999;144: 491-501.

105 Bekanntmachung der Richtlinien zur Gewinnung von Blut und Blutbestandteilen und zur Anwendung von Blutprodukten (Hämotherapie) gemäß $\S \S 12$ und 18 des Transfusionsgesetzes (TFG) (Novelle 2005) vom 19. September 2005. Bundesanzeiger 2005;57:209a, ausgegeben am Sonnabend, dem 5. November 2005.

106 Bekanntmachung der Richtlinien zur Gewinnung von Blut und Blutbestandteilen und zur Anwendung von Blutprodukten (Hämotherapie) gemäß $\S \S 12$ und 18 des Transfusionsgesetzes (TFG) (Änderungen und Ergänzungen 2007) vom 17. April 2007. Bundesanzeiger 2007;92:5075, ausgegeben am 19. Mai 2007.

107 Thomssen, R: Pocken als bioterroristische Bedrohung. Bundesgesundheitsbl Gesundheitsforsch Gesundheitsschutz 2003;46:965-975.

-108 Pütz MM, Alberini I, Midgley CM, Manini I, Montomoli E, Smith GL: Prevalence of antibodies to vaccinia virus after smallpox vaccination in Italy. J Gen Virol 2005;86:2955-2960.
109 Paran N, Suezer Y, Lustig S, Israely T, Schwantes A, Melamed S, Katz L, Preuss T, Hanschmann KM, Kalinke U, Erez N, Levin R, Velan B, Löwer J, Shafferman A, Sutter GJ: Postexposure immunization with modified vaccinia virus Ankara or conventional Lister vaccine provides solid protection in a murine model of human smallpox. Infect Dis 2009;199:39-48.

110 Parrino J, McCurdy LH, Larkin BD, Gordon IJ, Rucker SE, Enama ME, Koup RA, Roederer M, Bailer RT, Moodie Z, Gu L, Yan L, Graham BS; VRC 201/203 Study Team: Safety, immunogenicity and efficacy of modified vaccinia Ankara (MVA) against Dryvax challenge in vaccinianaïve and vaccinia-immune individuals. Vaccine 2007;25:1513-1525.

111 Jones T: IMVAMUNE, an attenuated modified vaccinia Ankara virus vaccine for smallpox infection. Curr Opin Mol Ther 2008;10:407-417.

112 Earl PL, Americo JL, Wyatt LS, Espenshade O, Bassler J, Gong K, Lin S, Peters E, Rhodes L Jr, Spano YE, Silvera PM, Moss B: Rapid protection in a monkeypox model by a single injection of a replication-deficient vaccinia virus. Proc Natl Acad Sci U S A 2008;105:10889-10894

113 Jordan R, Hruby D: Smallpox antiviral drug development: satisfying the animal efficacy rule. Expert Rev Anti Infect Ther 2006;4:277-289.

114 Yang G, Pevear DC, Davies MH, Collett MS, Bailey T, Rippen S, Barone L, Burns C, Rhodes G, Tohan S, Huggins JW, Baker RO, Buller RL, Touchette E, Waller K, Schriewer J, Neyts J, DeClercq E, Jones K, Hruby D, Jordan R: An orally bioavailable antipoxvirus compound (ST-246) inhibits extracellular virus formation and protects mice from lethal orthopoxvirus challenge. J Virol 2005;79:13139-13149.

115 Quenelle DC, Buller RML, Parker S, Keith KA, Hruby DE, Jordan R, Kern ER: Efficacy of delayed treatment with ST-246 given orally against systemic orthopoxvirus infections in mice. Antimicrob Agents Chemother 2007;51:689-695.

116 Grosenbach DW, Jordan R, King DS, Berhanu A, Warren TK, Kirkwood-Watts DL, Tyavanagimatt S, Tan Y, Wilson RL, Jones KF, Hruby DE: Immune responses to the smallpox vaccine given in combination with ST-246, a small-molecule inhibitor of poxvirus dissemination. Vaccine 2008;26:933-946.

117 Vora S, Damon IK, Fulginiti V, Weber SG, Kahana M, Stein SL, Gerber SI, Garcia-Houchin S, Lederman ER, Hruby D, Collins L, Scott D, Thompson K, Barson JV, Regnery RL, Hughes C, Daum RS, Li Y, Zhao H, Smith S, Braden Z, Karem K, Olson VA, Davidson WB, Trindade G, Bolken T, Jordan R, Tien D, Marcinak J: Severe eczema vaccinatum in a household contact of a smallpox vaccinee. Clin Infect Dis 2008;46:15551561.

118 Quenelle DC, Prichard MN, Keith KA, Hruby DE, Jordan R, Painter GR, Robertson A, Kern ER (2007) Synergistic efficacy of the combination of ST-246 with CMX001 against orthopoxviruses. Antimicrob Agents Chemother 51:4118-4124
119 Downie AW, Mccarthy K, MacDonald A: Viraemia in smallpox. Lancet 1950;2(6637):513-514.

120 Likos AM, Sammons SA, Olson VA, Frace AM, Li Y, Olsen-Rasmussen M, Davidson W, Galloway R, Khristova ML, Reynolds MG, Zhao H, Carrol DS, Curns A, Formenty P, Esposito JJ, Regnery RL, Damon IK: A tale of two clades: monkeypox viruses. J Gen Virol 2005;86:2661-2672.

121 Bray M: Pathogenesis and potential antiviral therapy of complications of smallpox vaccination. Antiviral Res 2003;58:101-114.

122 Srinivasan K, Akolkar PN, Taffs RE, Hewlett IK: Absence of detectable viremia in plasma and peripheral blood mononuclear cells from smallpox vaccinees: implications for blood safety. Transfusion 2006;46(9):1589-1592.

123 Cohen JI, Hohman P, Preuss C, Li L, Fischer SH, Fedorko DP: Detection of vaccinia virus DNA, but not infectious virus, in the blood of smallpox vaccine recipients. Vaccine 2007;25:4571-4574.

124 Fulginiti VA, Papier A, Lane JM, Neff JM, Henderson DA: Smallpox vaccination: a review, part I. Background, vaccination technique, normal vaccination and revaccination, and expected normal reactions. Clin Infect Dis 2003;37:241-250.

125 Fulginiti VA, Papier A, Lane JM, Neff JM, Henderson DA: Smallpox vaccination: a review, part II. Adverse events. Clin Infect Dis 2003;37:251-271.

126 Nitsche A, Kurth A, Pauli G: Viremia in human cowpox virus infection. J Clin Virol 2007;40:160 162.

127 Schmidt M, Roth WK, Meyer H, Seifried E, Hourfar MK: Nucleic acid test screening of blood donors for orthopoxviruses can potentially prevent dispersion of viral agents in case of bioterrorism. Transfusion 2005;45:399-403.

128 Amareld RW, Wersocki M, Drohan M, Drohan MN, Burgess WH, Mann M, Forng RY: Controlled gamma-irradiation mediated pathogen inactivation of human urokinase preparations with significant recovery of enzymatic activity. Biologicals 2003;31:261-264.

129 Remington KM, Trejo SR, Buczynski G, Li H, Osheroff WP, Brown JP, Renfrow H, Reynolds R, Pifat DY: Inactivation of West Nile virus, vaccinia virus and viral surrogates for relevant and emergent viral pathogens in plasma-derived products. Vox Sang 2004;87:10-18.

130 Roberts P: Resistance of vaccinia virus to inactivation by solvent/detergent treatment of blood products. Biologicals 2000;28:29-32.

131 Chandra S, Cavanaugh JE, Lin CM, Pierre-Jerome C, Yerram N, Weeks R, Flanigan E, Feldman F: Virus reduction in the preparation of intravenous immune globulin: in vitro experiments. Transfusion 1999;39:249-257.

132 Berting A, Goerner W, Spruth M, Kistner O, Kreil TR: Effective poxvirus removal by sterile filtration during manufacture of plasma derivatives. J Med Virol 2005;75:603-607.

133 Gubser C, Smith GL: The sequence of camelpox virus shows it is most closely related to variola virus, the cause of smallpox. J Gen Virol 2002;83:855-872 